\title{
IMPLEMENTASI STRATEGI BERMAIN PERAN UNTUK MENINGKATKAN HASIL BELAJAR SISWA KELAS 2 MIN 9 BANJAR
}

\author{
Rusdiana \\ MIN 9 Banjar \\ E-mail: rusd5851@gmail.com
}

\begin{abstract}
This study aims to improve the learning outcomes of class 2 MIN 9 Banjar students with role playing strategies. The research method used is Classroom Action Research (CAR) with a description of qualitative data. The research design used was Class Action Research with Kemmis and Mc Taggart models. The rare steps include: (1) planning, (2) action / action, (3) observation, and (4) reflection. The results of the research in the first cycle and second cycle showed that the role playing strategy improved the learning outcomes of class 2 MIN 9 Banjar students in the material knew fractions of currency values. Before the action is carried out, the cumulative total value of students is 2010 with a class average of 67.00. After the action of the first cycle was carried out, the average student learning outcomes increased to 71.66 with cumulative results of 2150 . In the second cycle the cumulative value of students increased rapidly to 2770 with an average value of 92.33 . After the second cycle, all students individually can achieve the KKM score.
\end{abstract}

Keywords: implementation; role playing; learning outcome.

\begin{abstract}
ABSTRAK
Penelitian ini bertujuan untuk peningkatan hasil belajar siswa kelas 2 MIN 9 Banjar dengan strategi bermain peran. Metode penelitian yang digunakan adalah Penelitian Tindakan Kelas (PTK) dengan deskripsi data kualitatif. Rancangan penelitian yang digunakan adalah Penelitian Tindakan Kelas dengan model Kemmis dan Mc Taggart. Langkah-langka model tersebut meliputi: (1) perencanaan, (2) aksi/tindakan, (3) observasi, dan (4) refleksi. Hasil penelitian pada siklus I dan siklus II menunjukkan bahwa strategi bermain peran meningkatkan hasil belajar siswa kelas 2 MIN 9 Banjar pada materi mengenal pecahan nilai mata uang. Sebelum tindakan dilakukan, total kumulatif nilai siswa adalah 2010 dengan rata-rata kelas 67.00. Setelah tindakan siklus I dilakukan, rata-rata hasil belajar siswa meningkat menjadi 71.66 dengan hasil kumulatif 2150 . Pada siklus II nilai kumulatif siswa meningkat pesat menjadi 2770 dengan nilai rata-rata 92.33. Setelah siklus II dilakukan, seluruh siswa secara individu mampu mencapai nilai KKM.
\end{abstract}

Kata Kunci: implementasi; bermain peran; hasil belajar.

\section{PENDAHULUAN}

Pada hakekatnya, pembelajaran merupakan interaksi anak dengan teman-temannya, dengan gurunya, dengan sumber belajar dan lingkungannya. Interaksi ini harus berada dalam lingkungan yang aman dan nyaman sehingga secara individual, proses belajar tersebut berjalan lancar pada setiap diri anak. Pembelajaran bagi anak haruslah bermakna. Dalam menerangkan pembelajaran bermakna ini, Ausubel memaparkan bahwa belajar haruslah berupa upaya mengaitkan informasi baru dengan konsep-konsep relevan yang terdapat dalam struktur kognitif anak.

Seorang guru haruslah mengenali karakteristik siswa sebelum merencanakan dan melaksanakan pembelajaran tematik ini. Kompetensi guru dan metode pengajaran yang 
dipilihnya sangat menentukan keberhasilan peserta didik. Pembelajaran tradisional yang pasif terbukti tidak dapat memenuhi ekspektasi untuk semaksimal mungkin mengembangkan potensi siswa dan menghadirkan kemampuan beradaptasi dengan lingkungannya.

Pembelajaran pada sekolah dasar kelas rendah, dalam bingkai kurikulum 2013, dilaksanakan melalui metode tematik integrative. Joni.T.R (1996;3) yang mengartikan pembelajaran tematik sebagai suatu sistem pembelajaran yang memungkinkan siswa baik secara individual maupun kelompok aktif mencari, menggali dan menemukan konsep serta prinsip keilmuan secara holistik, bermakna dan otentik. Pembelajaran tematik akan terjadi apabila peristiwa-peristiwa otentik atau eksplorasi tema menjadi pengendali dalam kegiatan pembelajaran. Dengan berpartisipasi dalam eksplorasi tema maka siswa akan sekaligus belajar tentang proses dan isi beberapa mata pelajaran secara serempak.

Makmun (1995) mengemukakan bahwa orientasi perkembangan siswa pada kelas rendah dalam setiap pembelajaran adalah untuk:

1. Mengembangkan konsep-konsep yang dipakai dalam kehidupan kesehariannya

2. Mengembangkan nilai-nilai emosi dan moralitas, mampu mengungkapkan kata hati dan perasaan

3. Mengembangkan kemandirian dan independensi pribadi

4. Mengembangkan kemampuan bersosialisasi terhadap kelompok

Melalui sebuah observasi dan dokumentasi yang dilakukan peneliti pada proses pembelajaran tematik di MIN 9 Banjar belum berjalan sesuai harapan. Rata-rata hasil belajar siswa dari berbagai mata pelajaran masih belum mencapai kriteria ketuntasan minimal (KKM). Pada pembelajaran pengenalan pengenalan nilai pecahan mata uang misalnya, nilai rata-rata siswa di kelas 2 MIN 9 Banjar adalah 68.8, sedangkan KKM yang ditetapkan adalah 70. Ada 12 siswa yang belum mampu mencapai ktiteria ketuntasan minimal tersebut.

Hasil observasi juga menunjukkan bahwa salah satu penyebab ketidakmampuan siswa untuk mencapai KKM adalah metode pembelajaran konvensional yang dilakukan oleh guru. Siswa hanya menjadi penerima informasi pasif. Guru mendominasi kelas dengan menjelaskan panjang lebar tentang mata uang, sejarahnya dan berbagai nilai pecahan mata uang tersebut. Karena pembelajaran hanya mampu mengaktifkan aspek auditori peserta didik, maka mereka kesulitan untuk menghubungkan tema dengan realita yang mereka alami. Padahal tema-tema tersebut dipilih sesuai dengan alam dan kehidupan manusia sekitar agar anak lebih mudah memahaminya.

Berdasarkan pemaparan di atas, peneliti berkeinginan untuk melaksanakan sebuah penelitian tindak kelas (PTK) sebagai salah satu usaha untuk memberikan solusi atas berbagai permasalahan pembelajaran yang teridentifikasi pada sekolah dasar kelas rendah. Salah satu jenis strategi pembelajaran yang memberi kesempatan kepada anak untuk belajar secara aktif adalah bermain peran atau yang dikenal dengan strategi role playing. Strategi ini sangat sesuai dengan karakteristik anak sekolah dasar kelas rendah. Strategi ini menghadirkan pembelajaran dalam konteks nyata. Siswa belajar melalui pengalaman konkrit. Mereka, dalam bermain peran, dapat menemukan masalah yang terjadi dalam hubungan kemanusiaan melalui situasi yang sudah disetting sebelumnya, dan kemudian mendiskusikannya. Melalui role playing, siswa dapat menemukan perasaan, persepsi, nilai dan strategi pemecahan masalah bersama-sama. Selain sesuai dengan karakteristik siswa, strategi bermain peran juga sejalan dengan karakteristik dari pembelajaran tematik sehingga dapat diindikasikan bahwa penggunaan strategi bermain peran dalam pembelajaran tematik pada siswa sekolah dasar kelas rendah dapat meningkatkan keefektifan pembelajaran, keterlibatan siswa dan hasil belajar mereka. 


\section{METODE PENELITIAN}

Metode yang digunakan dalam penelitian ini adalah Penelitian Tindakan Kelas yang merupakan ragam penelitian pembelajaran yang berkonteks kelas yang dilaksanakan oleh guru untuk memecahkan masalah - masalah pembelajaran yang dihadapi oleh guru, memperbaiki mutu dan hasil pembelajaran dan mencoba hal-hal baru dalam pembelajaran demi peningkatan mutu dan hasil pembelajaran. Penelitian Tindakan Kelas termasuk penelitian kualitatif meskipun data yang dikumpulkan bisa saja kuantitatif, dimana uraiannya bersifat deskriptif dalam bentuk kata-kata, peneliti merupakan instrument pertama dalam pengumpulan data, proses sama pentingnya dengan produk.

Rancangan penelitian yang digunakan adalah Penelitian Tindakan Kelas ini adalah model Kemmis dan Mc Taggart. Model PTK yang dikemukakan oleh Kemmis dan Mc Taggart adalah merupakan model pengembangan dari model Kurt Lewin. Dikatakan demikian, karena di dalam suatu siklus terdiri atas empat komponen, keempat komponen tersebut, meliputi: (1) perencanaan, (2) aksi/tindakan, (3) observasi, dan (4) refleksi. Sesudah suatu siklus selesai diimplementasikan, khususnya sesudah adanya refleksi, kemudian diikuti dengan adanya perencanaan ulang yang dilaksanakan dalam bentuk siklus tersendiri.

\section{HASIL PENELITIAN DAN PEMBAHASAN}

\section{A. Hasil Penelitian}

1. Siklus I

a. Persiapan Siklus I

Dalam tahap persiapan tindakan siklus I, guru melakukan langkah-langkah berikut:

1) menyiapkan RPP,

2) menyiapkan lembar observasi siswa,

3) menyiapkan lembar observasi guru,

4) menunjuk dua orang teman sejawat sebagai observer

5) menyiapkan soal evaluasi,

6) guru melakukan langkah-langkah persiapan kegiatan inti.

Pada pertemuan Hari Sabtu, 10 November 2018 sebelum pelaksanaan tindakan bermain peran, guru menginformasikan kepada siswa bahwa pertemuan yang membahas tentang pecahan nilai mata uang akan dilaksanakan dengan strategi bermain peran. Setting dalam bermain peran ini adalah sebuah pasar tradisional yang menjual berbagai kebutuhan pokok. Pasar tersebut hanya buka pada pagi hari, mulai pukul 06.00 wita hingga pukul 09.00 wita.

Guru meminta siswa untuk mengajukan diri sebagai partisipan dengan peran-peran yang sudah ditentukan. Ada 9 siswa yang mengajukan diri dan memilih peran yang ditentukan. Namun setting tersebut memerlukan 24 orang pemeran. Karena itu guru menunjuk siswa-siswa lain untuk mengisi peran yang kosong. Adapun siswa-siswa yang tidak memiliki peran yaitu sejumlah 6 orang, ditunjuk sebagai observer yang sekaligus merangkap sebagai pembeli.

Setelah masing-masing siswa mendapat peran, mereka ditugaskan untuk mengobservasi kegiatan jual beli di pasar tradisional pada hari minggu bersama orang tua mereka. Selain itu guru juga memberi tugas kepada masing-masing peran untuk membawa media, kostum atau alat permainan yang mendukung peran masing-masing. Adapun tugas untuk guru sendiri adalah menyediakan mata uang mainan yang nantinya akan digunakan sebagai alat transaksi dalam strategi bermain peran tersebut. 


\section{b. Pelaksanaan Tindakan Siklus I}

Pada Hari Rabu, 14 November 2018, strategi bermain peran diterapkan oleh guru. Saat masuk kelas, guru mengucapkan salam yang dijawab dengan serempak dan semangat oleh seluruh siswa. Pada hari itu, siswa sudah memakai kostum sesuai dengan peran masing-masing. Guru kemudian menunjuk seorang siswa untuk memimpin doa bersama di depan kelas.

Setelah berdoa bersama selesai, guru mengabsensi siswa kemudian menyiapkan media pembelajaran yaitu uang mainan dengan nominal dari Rp. 500 sampai Rp. 100.000 dan membagikannya kepada siswa. Nominal uang yang dimiliki siswa disesuaikan dengan peran yang dimainkannya. Seluruh siswa yang berperan sebagai pembeli menerima uang mainan dengan nominal yang lebih besar dan nilai pecahan uang yang besar pula. Adapun siswa yang berperan sebagai penjual hanya menerima nominal uang yang kecil dengan pecahan nilai uang yang kecil juga. Beberapa siswa sempat mempertanyakan keputusan guru dalam membagikan nominal mata uang mainan tersebut. Guru lalu menjelaskan bahwa uang yang dimiliki pembeli nantinya akan dipergunakan untuk membeli barang-barang yang dijual. Karena itu, penjual diberikan uang dengan pecahan nilai yang lebih kecil untuk memberikan kembalian harga dari pembeli. Setelah penjelasan guru, siswa kembali tenang.

Setelah itu, guru mengajak siswa bernyanyi bersama. Guru kemudian meminta salah seorang siswa untuk memimpin menyanyi di depan kelas. Judul lagu yang dinyanyikan adalah Kemarin Paman Datang. Haura kemudian maju untuk memimpin kegiatan menyanyi bersama tersebut. Teman-temannya memberikan tepuk tangan untuknya.

Siswa sempat meminta untuk menyanyi satu lagu lagi, namun guru mengingatkan bahwa waktu pembelajaran terbatas. Guru kemudian merangsang skemata siswa dengan melakukan tanya jawab mengenai pecahan nilai uang dan penggunaannya. Guru mengacungkan lembar demi lembar pecahan nilai mata uang dan menunjuk siswa untuk menjawab berapa nilai nominalnya dan memintanya membayangkan apa saja yang dapat ia beli dengan jumlah uang tersebut. Ada 2 siswa yang belum mampu menjawab pertanyaan guru tentang nominal mata uang yang ditunjukkan. Selain itu, 3 siswa belum tepat membayangkan apa yang bisa mereka beli dengan jumlah mata uang yang ditunjukkan. Ketiganya membayangkan benda yang harganya lebih mahal dari jumlah nominal uang yang ditunjukkan guru.

Kegiatan inti role playing diawali dengan pembacaan cerita yang dikarang oleh guru. Cerita memuat masalah yang dihadapi oleh seluruh siswa yang berperan sebagai pembeli. Dalam cerita itu, setiap siswa yang berperan sebagai pembeli menghadapi permasalahan masing-masing. salah satunya ada pembeli yang diminta orang tuanya untuk membelikan seikat bayam, dua buah jagung dan seekor ikan nila. Ia diberi uang sebanyak Rp. 20.000 rupiah. Namun pembeli tersebut juga ingin untuk membeli ice cream dan pentol. Sayangnya uangnya tidak cukup. Apa yang harus ia lakukan? Dari alur cerita yang dikarang oleh guru jelas terlihat bahwa role playing yang dilakukan ini dikombinasikan dengan strategi problem based learning.

Setelah pembacaan cerita bertemu dengan masalah-masalah yang dihadapi oleh setiap pemeran, guru kemudian menata panggung. Dalam hal ini guru mendiskusikan dengan siswa dimana dan bagaimana peran itu akan dimainkan. Apa saja kebutuhan yang diperlukan. Penataan panggung ini diatur dengan sederhana. Guru hanya membahas skenario tanpa dialog lengkap yang menggambarkan urutan permainan peran. Namun kesederhanaan penataan

panggung tertutupi oleh kemasmimalan siswa dalam menyiapkan kostum dan media pembelajaran.

Kegiatan observasi yang dilakukan siswa sebelum memainkan peran jelas sangat membantu mereka dalam melaksanakan dialog. Permainan peran dilaksanakan secara spontan. Memang terlihat masih ada siswa yang masih bingung memainkan perannya atau bahkan tidak 
sesuai dengan peran yang seharusnya ia lakukan. Selain itu, ada juga siswa yang hanya menonton saja tanpa aktif dalam dialog. Bahkan, ada yang memainkan peran yang bukan perannya. Ada siswa yang tiba-tiba ingin menjadi penjual dan menyuruh temannya bertukar peran. Ada juga siswa yang tidak mau membayar barang yang sudah dibelinya. Ada pula siswa yang salah memberikan uang kembalian bagi pembeli. Guru kemudian menghentikan permainan setelah ia menemukan banyak siswa yang melakukan dialog di luar plot yang ditentukan dan banyak peran yang berubah dari semestinya.

Guru mengajak siswa mendiskusikan permasalahan-permasalahan yang ditemuinya dalam permainan tadi dan melakukan evaluasi terhadap peran-peran yang dilakukan. Ada banyak usulan yang muncul. Ada siswa yang meminta untuk berganti peran. Alur cerita pun sedikit berubah. Namun karena waktu yang sempit, guru tidak melaksanakan permainan peran untuk kedua kalinya sebagai respon atas usulan-usulan yang didapatkan pada tahap evaluasi.

Guru langsung masuk ke tahapan kegiatan akhir, yaitu melakukan evaluasi. Guru memberikan lembar soal yang sudah dipersiapkan sebelumnya kepada para siswa untuk dijawab. Siswa diberikan waktu 20 menit untuk menyelesaikan 20 Soal. Ada beberapa siswa yang mampu menyelesaikan soal sebelum waktu habis. Namun lebih banyak siswa yang tidak mampu menyelesaikan soal karena kehabisan waktu. Guru kemudian menutup pertemuan tersebut dengan doa yang dipimpinnya sendiri dan menginformasikan kepada siswa tentang kemungkinan pengulangan strategi bermain peran pada pertemuan selanjutnya dengan tema yang sama.

\section{c. Observasi Guru Siklus I}

Pada siklus I, sangat terlihat guru kurang cakap dalam manajemen waktu. sebagian besar waktu dihabiskan pada tahap pembukaan pelajaran yang berupa absensi, menyanyi bersama dan apersepsi hingga persiapan media role playing dan pembagian uang mainan. Lebih 45 menit waktu dihabiskan guru pada tahap ini sehingga berimbas pada sempitnya waktu kegiatan inti.

Ada beberapa bagian dari kegiatan inti yang tidak dilaksanakan oleh guru karena mempertimbangkan waktu yang sempit, yaitu:

1) Menyiapkan observer dari siswa dan menjelaskan tugas-tugas mereka

2) Melakukan strategi bermain peran tahap kedua sebagai respon dari usulan-usulan dan perbaikan yang dihasilkan dari bermain peran tahap pertama

3) Melakukan diskusi dan evaluasi atas permainan peran tahap kedua

4) Mengajak siswa berbagi pengalaman dan merumuskan kesimpulan bersama.

Selain itu, kegiatan akhir pembelajaran pun tidak mampu dilaksanakan guru dengan maksimal. Guru melewatkan sesi tanya jawab tentang materi yang telah dipelajari untuk mengetahui hasil ketercapaian materi. Guru juga tidak memberi kesempatan kepada siswa untuk menyampaikan pendapatnya tentang pembelajaran yang telah diikuti. Akhirnya, waktu evaluasi yang seharusnya diberikan selama 30 menit terpotong menjadi 20 menit saja yang berdampak pada banyaknya siswa yang tidak mampu menyelesaikan evaluasi pada waktunya. Berdasarkan data observasi tersebut dapat dipersentasikan aktivitas guru sebagai berikut:

$$
\text { Nilai }=\underset{\text { Skor Maksimal }}{\text { Skor Perolehan }} \times 100 \%=23 \times 100 \%=69.69 \%
$$

Klasifikasi aktivitas guru yang digambarkan dari lembar observasi tersebut berada pada nilai $69.69 \%$. Nilai ini termasuk dalam rentang katagori cukup. 


\section{d. Observasi Siswa Siklus I}

Pada siklus ini, secara kumulatif dapat diakatakan bahwa strategi role playing dapat meningkatkan motivasi dan antusiasme siswa dalam mengikuti pelajaran. Dari observasi diketahui bahwa mayoritas siswa terlibat aktif dalam pembelajaran walaupun masih ada beberapa orang yang pasif dalam melakukan dialog. Siswa juga terlihat sangat gembira ketika pembelajaran dilaksanakan. Pada tahap evaluasi, mayoritas siswa berani mengungkapkan perasaan mereka tentang strategi bermain peran, berani memberikan kritik dan usulan. Namun yang perlu diperhatikan, terkadang siswa tidak bisa membatasi dirinya dalam memberikan kritik terhadap peran yang dimainkan oleh temannya sehingga terkesan bercanda. Berdasarkan data observasi dapat dipersentasikan aktivitas siswa sebagai berikut:

$$
\text { Nilai }=\underset{\text { Skor Maksimal }}{\text { Skor Perolehan }} \times 100 \%=\frac{14}{16} \times 100 \%=87.5 \%
$$

Klasifikasi aktivitas siswa yang digambarkan dari lembar observasi tersebut berada pada nilai $87.5 \%$. Nilai ini termasuk dalam rentang katagori baik sekali.

\section{e. Hasil Belajar Siswa Siklus I}

Setelah strategi role playing dilaksanakan pada kelas 2 MIN 9 Banjar pada materi pecahan nilai mata uang, guru melakukan evaluasi. Dalam evaluasi tersebut, guru memberikan 20 soal pilihan ganda kepada siswa. Hasil evaluasi individu tersebut dapat digambarkan melalui diagram berikut:

Tabel 1. Hasil Evaluasi Individu Sebelum dan Sesudah Tindakan pada Siklus I

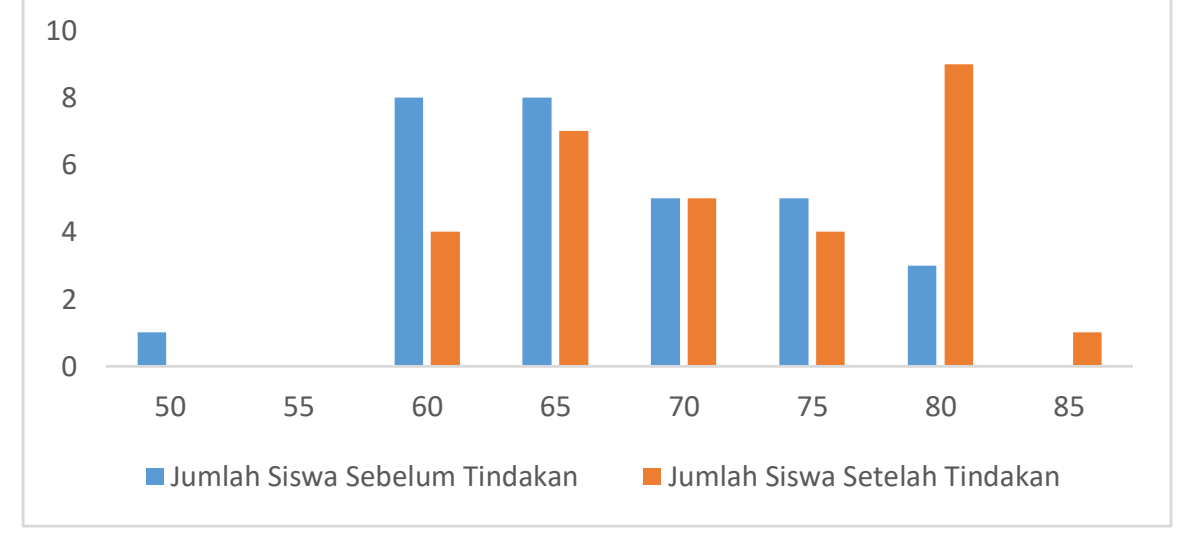

Total nilai siswa setelah mendapat tindakan adalah 2150 dengan nilai rata-rata 71.66. Sebelumnya, nilai rata-rata siswa adalah 67.00. Ada kenaikan nilai rata-rata kelas sebanyak 4.66 poin. Sebenarnya nilai rata-rata siswa ini telah mampu melampaui nilai KKM sehingga secara klasikal, pembelajaran di kelas 2 MIN 9 Banjar dapat dikatakan tuntas. Selain itu, persentase ketidaklulusan siswa dalam mencapai KKM juga menurun dari yang awalnya $56.6 \%$ menjadi $36.66 \%$. Namun karena masih ada 11 orang siswa yang nilai individualnya masih berada di bawah KKM, maka diputuskan penelitian tindakan kelas ini dilanjutkan ke siklus II. Adapun perbaikan di siklus II nantinya berpedoman pada hasil refleksi yang didapatkan dari siklus I. 


\section{f. Refleksi Siklus I}

Ada tiga isu penting yang harus mendapat perhatian khusus dalam refleksi siklus I ini agar nantinya siklus II dapat mencapai tujuan yang diharapkan. Dengan memperhatikan tiga isu ini, kemungkinan besar seluruh permasalahan yang dihadapi guru dan siswa di siklus I dapat diberikan solusi yang tepat. Tiga isu penting tersebut adalah:

1) Ketidakmampuan guru menjalankan proses pembelajaran sesuai alokasi waktu

2) Masih adanya beberapa siswa yang terlihat malu atau sungkan dalam memainkan peran mereka.

3) Ketidakmampuan siswa memahami tujuan pembelajaran

Ketidakmampuan guru menjalankan proses pembelajaran sesuai alokasi waktu berimbas pada dihilangkannya beberapa kegiatan inti pada strategi role playing. Kegiatan-kegiatan tersebut adalah pemberian deskripsi tugas bagi siswa yang berperan rangkap sebagai observer, ditiadakannya permainan peran untuk kali kedua sebagai implementasi perbaikan-perbaikan, kritik dan saran dari proses bermain peran yang sudah dilakukan, ditiadakannya diskusi dan evaluasi tahap kedua dan dilewatinya kegiatan berbagi pengalaman dan simpulan menurut perspektif masing-masing siswa.

Selain dampak-dampak di atas, proses pembelajaran yang tidak sesuai alokasi waktu juga mengakibatkan kegiatan penutup menjadi terganggu. Salah satu kegiatan penting yang dilewatkan oleh guru adalah memberikan penghargaan atas keaktifan siswa dalam proses pembelajaran. Padahal, penghargaan dari guru merupakan salah satu factor yang dapat meningkatkan motivasi siswa dan membangkitkan rasa percaya diri dalam belajar.

Alokasi waktu pada tahap evaluasi pun menjadi dipersempit yang awalnya sebanyak 30 menit menjadi hanya 20 menit. Alokasi waktu yang tidak sesuai ini kemungkinan besar berkorelasi terhadap rendahnya nilai siswa. Dari wawancara ditemukan bahwa banyak siswa yang mengaku bahwa mereka tidak dapat menyelesaikan seluruh soal yang ditanyakan pada lembar evaluasi karena kehabisan waktu.

Pada kegiatan pra pembelajaran, guru tidak menjelaskan tujuan pembelajaran beserta strategi yang akan digunakan dalam membahas tema pembelajaran. Hal inilah yang menyebabkan siswa tidak memahami tujuan pembelajaran dan nilai-nilai yang diajarkan. Siswa, dengan metode role playing, memang terlihat sangat aktif dan bersemangat menjalani proses belajar. Namun keaktifan tersebut tidak berada dalam koridor yang ditentukan sehingga tidak menemui hasil. Dari hasil wawancara dapat disimpulkan bahwa sebagian besar siswa tidak memahami esensi materi yang diajarkan kepada mereka, namun mereka mengakui bahwa proses pembelajaran yang telah mereka jalani sangat menyenangkan.

Pada kegiatan akhir pembelajaran, guru juga tidak merefleksi pemahaman siswa tentang materi yang sudah diajarkan dan langsung ke tahap evaluasi sehingga guru tidak mengetahui apakah esensi, nilai-nilai dan tujuan pembelajaran sudah tercapai atau tidak. Guru hanya mengandalkan lembar evaluasi untuk menilai keberhasilan pembelajaran. Padahal lembar evaluasi hanya mampu menyajikan nilai kognitif, sedangkan nilai afektif dan psikomotorik tidak tercover dengan baik.

Selain beberapa permasalahan yang disebut di atas, pada tahap refleksi ini juga akan disebutkan beberapa nilai lebih yang sudah dilakukan oleh guru dan siswa. Nilai-nilai tersebut seharusnya dipertahankan, bahkan ditingkatkan agar tujuan pembelajaran dapat tercapai dengan maksimal. Pembelajaran telah dilaksanakan oleh guru secara runtut sesuai RPP, walaupun ada beberapa segmen yang sengaja dilewatkan. Keruntutan pembelajaran ini menunjukkan bahwa bermain peran dapat berjalan dengan lancar selain kendala pada alokasi waktu. 
Keaktifan, keterlibatan dan antusiasme siswa dalam menjalani pembelajaran meningkat dengan pesat. Hal ini dapat dilihat melalui lembar observasi siswa yang menunjukkan bahwa keaktifan siswa mendapat nilai $87.5 \%$ dan berada pada katagori baik sekali. Hal ini juga berimbas pada meningkatnya nilai rata-rata kelas dari 67.00 menjadi 71.66. selain itu, jumlah siswa yang mengalami ketidaktuntasan belajar karena tidak mampu mencapai nilai KKM berkurang dari yang awalnya 17 siswa menjadi 11 siswa.

Dalam proses pembelajaran dengan strategi role playing, kepercayaan diri siswa juga meningkat. Terbukti mayoritas siswa berani memainkan peran mereka secara spontan dan terlihat menikmatinya. Selain itu, siswa-siswa juga aktif dalam mengajukan pertanyaan, kritik dan saran perbaikan pada tahap evaluasi strategi bermain peran. Taktik guru untuk memaksimalkan alokasi waktu untuk implementasi strategi dengan melakukan beberapa kegiatan berikut sebelum pelaksanaan tindakan harus dipertahankan. Kegiatan-kegiatan tersebut adalah:

1) Guru menjelaskan strategi bermain peran

2) Guru menjelaskan setting bermain peran

3) Guru membagi peran pada masing-masing siswa

4) Guru meminta siswa untuk mengobservasi peran yang akan mereka mainkan ke setting realistis bersama orang tua mereka

5) Guru meminta siswa menyiapkan kostum sederhana sesuai peran yang dimainkan siswa

\section{Siklus II}

\section{a. Persiapan Siklus II}

Dalam tahap persiapan tindakan siklus II, guru melakukan langkah-langkah yang tidak berbeda dari siklus sebelumnya, yaitu sebagai berikut:

1) menyiapkan RPP,

2) menyiapkan lembar observasi siswa,

3) menyiapkan lembar observasi guru,

4) menunjuk dua orang teman sejawat sebagai observer

5) menyiapkan soal evaluasi,

6) guru melakukan langkah-langkah persiapan kegiatan inti.

Sebelum melaksanakan tindakan siklus II, guru memperhatikan segala kekurangan-kekurangan yang ada pada siklus I untuk dilakukan perbaikan. Hal pertama yang dilakukan guru adalah reorganisasi alokasi waktu dengan kegiatan pembelajaran. Kegiatan-kegiatan yang dapat dilakukan di luar waktu tindakan, dipersiapkan terlebih dahulu oleh guru.

Seperti siklus sebelumnya, sebelum siklus II dilaksanakan, guru menjelaskan kepada siswa tentang strategi yang akan digunakan dalam mempelajari materi nilai pecahan uang, yaitu strategi bermain peran. Sebagian besar siswa sudah memahami prosedur strategi ini. Namun yang belum dipahami siswa adalah urgensi strategi dalam mencapai tujuan pembelajaran. Pada tahap ini, guru lebih banyak memberikan pengarahan tentang tujuan yang akan dicapai setelah pembelajaran dengan menggunakan strategi bermain peran selesai dilaksanakan. Guru juga meminta masing-masing siswa untuk mengevaluasi diri mereka sendiri nantinya setelah pembelajaran selesai; apakah mereka sudah mencapai tujuan pembelajaran atau tidak.

Langkah selanjutnya, guru menjelaskan setting yang akan digunakan dalam bermain peran. Setting ini tidak jauh berbeda dengan setting terdahulu di siklus I. memang ada beberapa tambahan yang dimasukkan guru yaitu menginternalisasi unsur-unsur pasar modern dalam pasar tradisional. Hal ini dimaksudkan agar siswa lebih memahami penggunaan pecahan nilai mata uang, khususnya dengan nominal yang besar. 
Guru tidak lupa memberikan deskripsi tugas kepada observer sehingga mereka mendapatkan arahan yang jelas. Hal ini tidak dilakukan sebelumnya oleh peneliti pada siklus I. Dengan adanya deskripsi tugas observer, diharapkan hasil evaluasi strategi dalam setiap tahap dapat menjadi lebih objektif dan usulan-usulan yang diberikan menjadi lebih konstruktif. Untuk siswa-siwa yang berperan sebagai observer, guru memilih siswa yang memiliki kedewasaan lebih dari siswa lainnya dan yang memiliki pengaruh di kelas.

Sebelum pengarahan berakhir, guru kembali mengingatkan kepada para siswa agar mereka kembali meluangkan waktu untuk mengobservasi peran yang akan mereka mainkan di pasar-pasar dekat rumah mereka bersama orang tua. Observasi ini telah terbukti memberikan inspirasi kepada siswa dalam memainkan peran mereka walaupun secara spontan. Melalui observasi, siswa secara tidak langsung juga belajar dari realita.

\section{b. Pelaksanaan Tindakan Siklus II}

Pada hari Senin, 19 November 2018, siklus II dilaksanakan. Guru masuk kelas dan mengucapkan salam yang dijawab serempak oleh para siswa. Guru kemudian berdiri di depan kelas dan mengabsen masing-masing siswa. Setelah absensi selesai, guru meminta ketua kelas untuk memimpin doa dari tempat duduknya sendiri. Untuk membangkitkan semangat siswa, guru memulai pembelajaran dengan tepuk anak sholeh. Hal ini berbeda dengan siklus sebelumnya dengan bernyanyi bersama. Keputusan guru ini merupakan salah satu taktik untuk memaksimalkan waktu pembelajaran.

Guru langsung melakukan warming up dengan membacakan sebuah cerita. Ketika alur cerita sampai kepada masalah-masalah yang ditemui oleh setiap pemeran, maka bermain peran dimulai. Siswa terlihat sangat antusias memulai peran mereka masing-masing. Tidak terlihat lagi siswa yang pasif dan malu berdialog. Mereka seperti sudah terbiasa dengan peran yang mereka mainkan.

Setelah waktu bermain peran tahap pertama habis, guru menghentikan strategi dan meminta siswa duduk membentuk lingkaran. Guru memancing siswa untuk mengungkapkan kendala-kendala yang mereka temui saat memainkan peran masing-masing. Guru juga meminta observer untuk menyerahkan hasil observasi mereka. Tidak banyak kritik yang ditemukan pada permainan peran kali ini. Mayoritas siswa mampu memainkan peran mereka dengan tepat.

Permainan peran kembali dilanjutkan. Masing-masing peran aktif dalam melakukan dialog. Transaksi jual beli terlihat lancar. Memang ada beberapa siswa yang tidak tepat menghitung berapa uang yang harus dibayar atau berapa uang kembalian. Tapi masalah ini cepat selesai dengan bantuan teman lainnya. Hampir seluruh siswa yang berperan menjadi pembeli menghabiskan uang yang diberikan kepadanya. Hal ini patut menjadi perhatian guru agar mengajarkan sikap hemat dan membuat skala prioritas dalam berbelanja.

Bermain peran dihentikan oleh guru tepat pada waktunya. Guru kembali meminta siswa untuk duduk membentuk lingkaran. Siswa-siswa dipersilahkan mengungkapkan permasalahan yang mereka temui saat bermain peran, memberikan usulan atau membagikan pengalaman dan perasaan mereka tentang pembelajaran kali ini. Masalah yang ditemui siswa hanya berkisar pada berapa uang yang harus dibayar atau berapa uang yang harus dikembalikan. Tidak banyak masalah yang diungkapkan siswa. Mereka lebih banyak menceritakan pengalaman dan perasaan juga simpulan mereka tentang pembelajaran. Mereka merasa senang dengan strategi ini karena dapat belajar dalam bermain. Mereka juga sangat aktif dalam mengkonstruksi informasi baru dan menautkannya dengan informasi yang sudah mereka ketahui melalui kehidupan sehari-hari. Para siswa meminta guru agar mengajar dengan strategi serupa pada tema-tema lainnya. 
Guru bersama para siswa menarik simpulan tentang materi pecahan nilai uang. Guru juga merangsang tanggapan siswa terhadap ilustrasi-ilustrasi yang dibuat guru, misalnya jika siswa ingin membeli sesuatu yang tidak terlalu penting, kemudian ada pengemis yang meminta uangnya untuk makan, apa yang harus siswa lakukan? Atau ada buku yang harus dibeli siswa agar menambah ilmu, tetapi ia tidak memiliki uang untuk membelinya. Apakah ia harus menghemat uang jajannya atau malah meminta orang tua membelikan buku sedangkan ia menghabiskan uang jajan? Ilustrasi-ilustrasi tersebut dapat meningkatkan ranah afektif siswa supaya lebih peka terhadap keadaan sekitarnya.

Waktu pelajaran tersisa 30 menit. Guru mempersilakan siswa untuk mengerjakan lembar evaluasi. Seluruh siswa menyelesaikan lembar evaluasi tersebut sebelum waktu habis. Ketika waktu tersisa 25 menit, seluruh siswa sudah selesai dengan tugasnya. Guru kemudian memimpin doa dan menutup pembelajaran pada hari itu.

\section{c. Observasi Guru Siklus II}

Pada siklus II, guru terlihat sangat concern dalam memperbaiki permasalahanpermasalahan yang dialaminya dalam siklus sebelumnya. Manajemen waktu yang sebelumnya tidak bisa ditangani guru, pada siklus ini terlihat berjalan sesuai rencana. Guru juga mampu mengkondusifkan kelas karena para siswa sudah memahami tujuan pembelajaran mereka. Memang strategi bermain peran ini sangat memicu antusiasme siswa ketika pertama kali mencobanya sehingga tidak jarang mereka keluar jalur. Pada siklus II, hal tersebut tidak lagi ditemukan.

Aktivitas guru pada siklus II hampir sempurna. Namun ada satu poin yang tidak dilakukan guru, yaitu membahas scenario bermain peran bersama siswa. Mungkin guru berpendapat bahwa kegiatan ini tidak terlalu penting dikarenakan siswa sudah menjalani scenario yang sama pada siklus I dan pemahaman mereka terhadap scenario juga didukung oleh observasi yang mereka lakukan bersama orang tua.

Selain itu, guru juga lupa memberi penghargaan secara khusus kepada siswa di akhir pembelajaran. Hal ini mungkin dikarenakan pada tahap sharing pengalaman dan pendapat para siswa tentang pembelajaran yang telah mereka lalui, guru sudah beberapa kali memberikan pujian. Seluruh siswa memang terlihat aktif dan antusias dalam belajar. Berdasarkan data observasi tersebut dapat dipersentasikan aktivitas guru sebagai berikut:

$$
\text { Nilai }=\underset{\text { Skor Maksimal }}{\text { Skor Perolehan }} \times 100 \%=\frac{31}{33} \times 100 \%=93.93 \%
$$

Klasifikasi aktivitas guru yang digambarkan dari lembar observasi tersebut berada pada nilai 93.93\%. Nilai ini termasuk dalam rentang katagori baik sekali.

\section{d. Observasi Siswa Siklus II}

Aktivitas siswa pada siklus II tidak jauh berbeda dengan aktivitas mereka dalam siklus I. Mereka masih terlihat bersemangat dan antusias dalam mengikuti pelajaran dengan strategi bermain peran. Kepercayaan diri siswa juga terlihat terbina dengan baik. Mereka berani mengungkapkan pendapat, memberikan masukan dan mengekspresikan perasaan. Pada siklus II, tidak terlihat lagi siswa yang malu, sungkan atau pasif dalam menjalani pembelajaran. Mereka sidah berani berbaur dengan teman lainnya dan aktif melakukan dialog juga memainkan perannya.

Satu hal yang mungkin terlihat berbeda dalam aktivitas siswa pada siklus II adalah mereka terlihat lebih terkontrol dalam memerankan peran. Hal ini dikarenakan guru telah 
memberikan penjelasan mengenia tujuan dari pemebelajaran yang harus mereka capai setelah pelajaran selesai.

Hanya saja, dikarenakan guru tidak memberikan penjelasan tentang scenario bermain peran kepada siswa karena alasan-alasan yang telah disebutkan sebelumnya, maka pada tahap ini siswa juga tidak memperhatikan scenario yang diberikan guru. Jika seandainya tahap pemberian scenario itu ada, kemungkinan besar siswa juga akan memperhatikan dengan seksama. Hal ini mengurangi kesempurnaan aktivitas siswa pada siklus II. Berdasarkan data observasi tersebut dapat dipersentasikan aktivitas siswa sebagai berikut:

$$
\text { Nilai }=\underset{\text { Skor Maksimal }}{\text { Skor Perolehan }} \times 100 \%=\frac{15}{16} \times 100 \%=93.75 \%
$$

Klasifikasi aktivitas siswa yang digambarkan dari lembar observasi tersebut berada pada nilai 93.75\%. Nilai ini termasuk dalam rentang katagori baik sekali.

\section{e. Hasil Belajar Siswa Siklus II}

Implementasi strategi bermain peran telah mampu menumbuhkan keaktifan siswa mencapai $93.75 \%$ yang berada dalam kategori baik sekali. Setiap siswa telah mampu menunjukkan keaktifan belajar secara optimal dalam mencapai tujuan pembelajaran. Keaktifan dan keterlibatan siswa dalam pembelajaran yang meningkat secara tidak langsung dapat mewujudkan suasana belajar yang harmonis, aktif dan interaktif. Kondisi ini mengisyaratkan pula bahwa penerapan strategi bermain peran berdampak positif bagi tumbuh kembangnya budaya belajar serta dapat membantu siswa lain yang masih kesulitan memahami materi. Kegiatan belajar siswa yang berlangsung secara kondusif, efektif dan efisien dalam suasana yang menyenangkan juga berdampak positif pada kenaikan hasil belajar mereka.

Berikut ini adalah diagram peningkatan hasil belajar siswa dari sebelum tindakan, siklus I hingga siklus II:

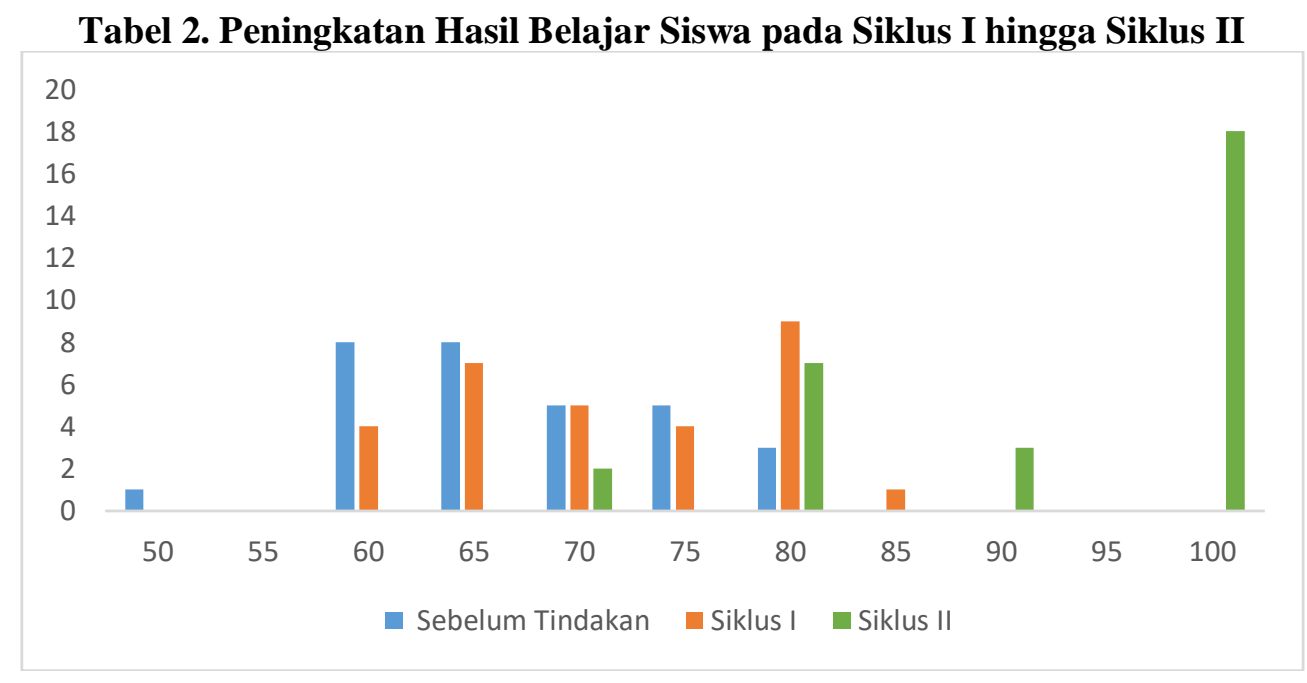

Total nilai siswa setelah mendapat tindakan pada siklus I adalah 2150 dengan nilai ratarata 71.66. Jumlah siswa yang belum mampu mencapai KKM setelah siklus I dilakukan adalah 11 orang dengan persentase $36.66 \%$. Setelah siklus II dilaksanakan, seluruh siswa secara individu dapat mencapai KKM. Nilai kumulatif siswa meningkat pesat menjadi 2770 dengan nilai rata-rata 92.33. Dengan demikian maka PTK dianggap selesai. 


\section{f. Refleksi Siklus II}

Terjadinya peningkatan hasil belajar siswa dilihat dari nilai evaluasi ini tidak terlepas dari aktivitas siswa dan guru yang memotivasi siswa untuk aktif dalam proses pembelajaran dengan menggunakan model pembelajaran bermain peran yang berbeda pada tiap pertemuan. Sesuai dengan pendapat ahli yang mengatakan bermain peran adalah suatu cara penguasaan bahan pelajaran melalui pengembangan imajinasi dan penghayatan siswa. Pengembangan imajinasi dan penghayatan dilakukan siswa dengan berperan sebagai tokoh yang ditentukan dalam skenario.

Segala kekurangan yang ditemui guru pada pelaksanaan strategi bermain peran di siklus I sudah dapat diatasi pada siklus II. Hal ini dibuktikan dengan peningkatan nilai aktivitas guru dari hasil observasi. Pada siklus II ini, guru dapat melaksanakan pembelajaran sesuai dengan RPP. Pembelajaran dilaksanakan secara runtut. Alokasi waktu tiap segmen pembelajaran terjaga dengan baik. Karena itu, guru mendapat nilai $93.93 \%$ yang berada pada rentang katagori baik sekali.

Cuma ada satu hal yang terlewatkan oleh guru yang menyebabkan ia tidak mendapatkan nilai sempurna, yaitu menjelaskan scenario bermain peran kepada siswa. Guru beranggapan bahwa skenario tersebut sudah dipahami siswa bermodalkan hasil observasi mereka bersama orang tua dan pengalaman yang didapatkan ketika melaksanakan strategi yang sama di siklus I. padahal hal tersebut merupakan kegiatan inti yang harus dilakukan guru, paling tidak sebagai informasi penguat.

Nilai observasi aktifitas siswa juga meningkat. Pada siklus I, para siswa sudah mendapatkan nilai observasi yang tinggi karena keaktifan mereka dalam pembelajaran. Hanya saja pada saat itu, pembelajaran berjalan kurang kondusif dan para siswa belum memahami tujuan pembelajaran sehingga bermain peran yang mereka lakukan hanya sekedar bersenangsenang. Hal ini sudah diantisipasi oleh guru dengan memberikan pengarahan kepada siswa sebelum siklus II dimulai. Karena itulah, keaktifan siswa di siklus II berada pada katagori baik sekali dengan nilai $93.75 \%$.

Setelah siklus II selesai, nilai individu siswa meningkat hingga seluruh siswa dapat mencapai KKM. Nilai rata-rata kelas pun mengalami peningkatan signifikan dari 71.66 menjadi 92.33. keberhasilan seluruh siswa mencapai KKM menandai kesuksesan strategi bermain peran dalam meningkatkan hasil belajar siswa.

\section{B. Pembahasan}

Faktor utama penyebab ketidakmampuan siswa dalam mencapai KKM pada materi pecahan nilai uang adalah sikap pasif mereka selama proses pembelajaran. Padahal, dalam kehidupan sehari-hari, mereka sering berinteraksi dengan berbagai pecahan nilai uang. Sebelum dilakukan tindakan, nilai rata-rata siswa hanya 67.00. Nilai ini kurang tiga poin dari kriteria ketuntasan minimal.

Walaupun terjadi pergeseran pendekatan pembelajaran dari teacher centered learning ke student centered learning, implementasi strategi bermain peran tetap menjadikan guru sebagai salah satu factor penentu keberhasilan belajar. Guru memang tidak lagi menjadi sumber belajar satu-satunya, namun ia sekarang menjadi fasilitator pembelajaran. Guru malah dituntut lebih kreatif dan inovatif dalam merancang pembelajaran agar bisa meningkatkan keterlibatan siswanya. Ketidakmampuan guru mengelola pembelajaran bisa mengakibatkan kegagalan belajar. Hal ini seperti yang dialami guru ketika melaksanakan strategi bermain peran pada siklus I. guru tidak mampu mengarahkan siswa mencapai tujuan pembelajaran, mengkondusifkan kelas dan mengelola alokasi waktu. Memang terdapat peningkatan pada hasil 
belajar siswa, namun hal itu lebih dikarenakan karakteristik strategi yang menuntut siswa untuk mengaktifkan banyak panca indranya dalam belajar dan memberikan rasa gembira ketika prosesnya berlangsung.

Pada siklus I, aktivitas guru berada pada poin 69.69\%. Nilai ini termasuk dalam rentang katagori cukup. Evaluasi hasil belajar siswa di siklus I memang mengalami peningkatan daripada sebelum mendapat tindakan. Secara klasikal, nilai rata-rata kelas sudah berada di atas nilai KKM. Namun masih ada siswa yang secara individual tidak mampu mencapai KKM. Setelah dilakukan refleksi terhadap proses pembelajaran di siklus I, guru kemudian mengadakan perbaikan-perbaikan dan merumuskan taktik agar pembelajaran dapat berlangsung sesuai rencana. Hal ini terbukti dengan adanya peningkatan poin aktivitas guru pada siklus II. Guru mendapatkan poin $93.93 \%$. Nilai ini termasuk dalam rentang katagori baik sekali. Peningkatan poin aktivitas guru berimbas langsung pada peningkatan hasil belajar siswa. Setelah siklus II dilaksanakan, seluruh siswa dapat mencapai nilai KKM.

Perasaan senang yang dialami siswa dalam menjalankan kegiatan bermain peran (role playing) menjadi salah satu faktor yang mendukung materi atau tujuan dari kegitan tersebut akan mudah dipahami oleh subjek. Hal tersebut sejalan dengan apa yang diungkapkan Siti Hadija (2013: 105) mengenai bermain sebagai kegiatan yang disenangi oleh anak, sehingga dalam perasaan senang, anak akan lebih bersedia mengikuti permainan dan lebih mudah memahami pesan yang ada dalam permainan tersebut. Hal ini sejalan dengan hasil observasi aktivitas siswa. Pada pelaksanaan strategi bermain peran siklus I, keaktifan siswa langsung meningkat drastis ke poin $87.5 \%$. Nilai ini termasuk dalam rentang katagori baik sekali. Namun seperti yang biasanya terjadi pada awal-awal penggunaan strategi ini, siswa sedikit lepas kontrol ketika memainkan peran mereka. Siswa lebih banyak bercanda dengan teman-temannya sehingga fokus pembelajaran menjadi buyar. Hal ini diperkuat dengan tidak adanya kegiatan pemahaman tujuan pembelajaran yang dilakukan oleh guru. Keadaan tersebut berubah menjadi lebih kondusif pada siklus II setelah guru memperbaiki segala kekurangan pada siklus I. Klasifikasi aktivitas siswa yang digambarkan dari lembar observasi siklus II meningkat menjadi 93.75\%. Nilai ini termasuk dalam rentang katagori baik sekali.

Semakin banyak pancaindra yang digunakan maka semakin banyak dan semakin jelas pula pengertian atau pengetahuan yang diperoleh. Pengalaman-pengalaman yang melibatkan penglihatan, pendengaran, sentuhan, rasa atau gerakan yang jelas, mampu meningkatkan daya serap ke memori, sehingga lebih mudah diingat. Dari wawancara yang dilakukan kepada siswa setelah mereka selesai menjalani pembelajaran dengan strategi bermain peran, diketahui hasil berikut:

Tabel 3. Hasil Wawancara Siswa tentang Pembelajaran dengan Strategi Bermain Peran

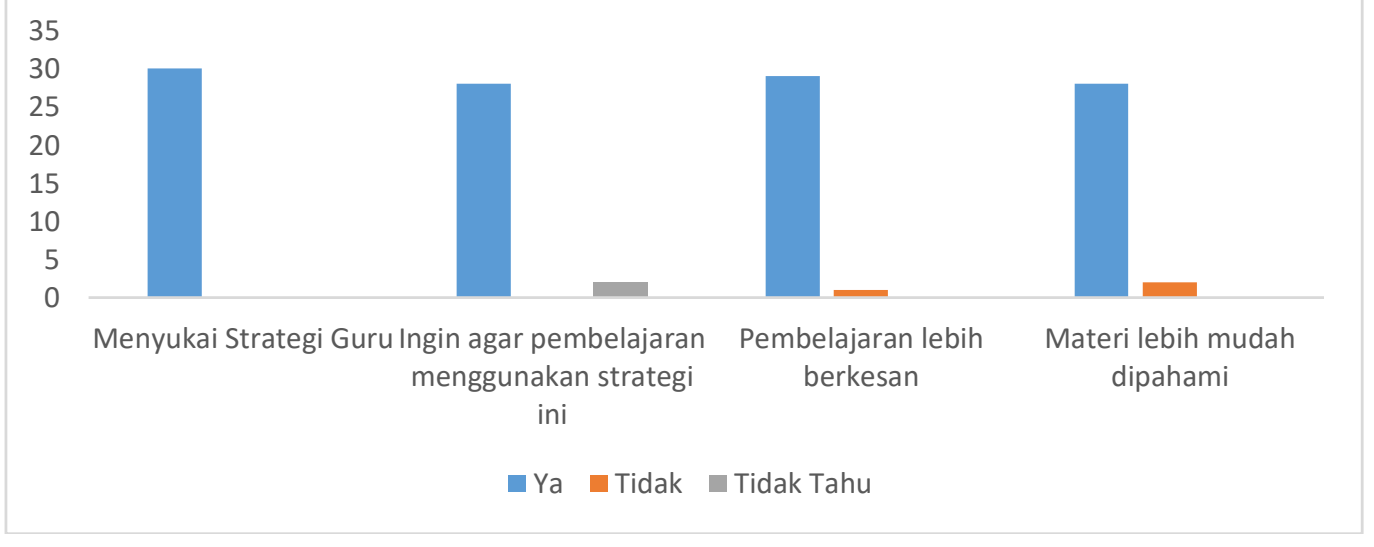


Seluruh siswa mengakui bahwa mereka menyukai strategi yang dipraktekkan oleh guru, yaitu bermain peran. Namun memang ada beberapa siswa yang masih terlihat malu ketika pertama kali strategi ini dijalankan. Pada siklus II, siswa-siswa yang tadinya malu, tidak berani, atau tidak percaya diri dalam memainkan perannya sudah tidak terlihat lagi. Kepercayaan diri mereka meningkat ketika melihat teman lainnya menikmati permainan. Sebanyak 28 siswa menginginkan strategi ini diterapkan pada pembelajaran-pembelajaran selanjutnya karena mereka merasa gembira dengan strategi tersebut. Namun ada 2 siswa yang menjawab tidak tahu. Setelah dikonfirmasi, jawaban mereka dikarenakan mereka tidak yakin bisa memerankan seluruh peran yang nantinya dibebankan kepada mereka dalam skenario yang berbeda.

Mengenai kesan pembelajaran, 29 siswa menyatakan bahwa dengan strategi bermain peran, pembelajaran menjadi lekat dalam ingatan mereka. Mereka mudah mengingat hal-hal yang membuat mereka bergembira. Memang ada 1 orang yang menjawab tidak dengan alasan bahwa yang tadi mereka lakukan adalah bermain, bukan belajar. Dalam benaknya, belajar adalah kegiatan mendengarkan dan menulis materi yang diberikan guru. Kesalahan mindset ini bukan berasal dari siswa itu sendiri, namun lebih kepada bagaimana guru merancang sebuah pembelajaran.

Ada 28 siswa yang menyatakan materi lebih mudah dipahami dengan strategi ini karena mereka belajar dengan mengaktifkan hampir seluruh panca indranya. Memang ada 2 siswa yang memberikan jawaban bahwa strategi bermain peran tidak memberi kemudahan bagi mereka dalam memahami materi. Jawaban tersebut, setelah dikonfirmasi, ternyata dikarenakan guru tidak memberikan penjelasan tentang tujuan pembelajaran sehingga mereka tidak mampu mengevaluasi diri sendiri apakah sudah mencapai tujuan pembelajaran atau tidak.

Penggunaan alat permainan edukatif dalam bermain peran (role playing) memiliki manfaat yang luar biasa dalam mendukung konstruksi keilmuan siswa. Alat permainan edukatif merupakan alat permainan yang dapat mengoptimalkan perkembangan anak sesuai usia dan tingkat perkembangannya dan yang berguna untuk pengembangan aspek fisik, behasa kognitif, dan sosial anak". Dalam strategi bermain peran yang dijalankan oleh guru, penggunaan alat permainan seperti uang mainan, berbagai barang dagangan mainan hingga kostum yang digunakan siswa selama bermain peran ternyata mendukung dan mempermudah pemahaman mereka terhadap materi yang diajarkan. Keaktifan belajar disertai rasa gembira, strategi yang sesuai dengan karakteristik siswa, dan penggunaan alat permainan atau peraga edukatif terbukti dapat mendongkrak hasil belajar mereka. Hal ini dapat dilihat dari peningkatan hasil belajar yang signifikan dari sebelum pemberian tindakan, siklus I hingga siklus II. Berikut ini diagram peningkatan rata-rata hasil belajar siswa:

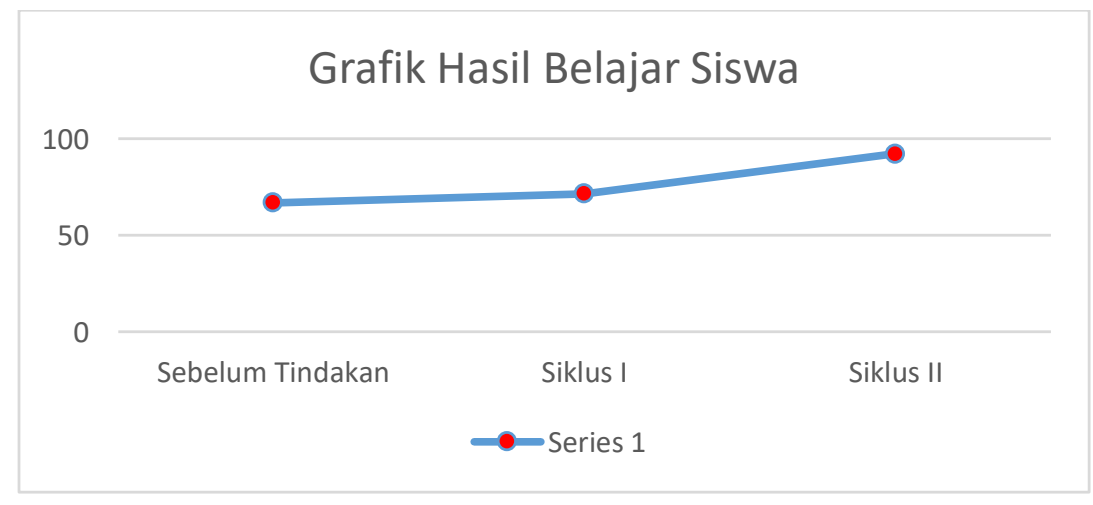

Gambar 1. Peningkatan Rata-Rata Hasil Belajar Siswa 
Sebelum tindakan dilakukan, total kumulatif nilai siswa adalah 2010 dengan rata-rata kelas 67.00. Nilai klasikal ini berada di bawah KKM, yaitu 70. Setelah tindakan siklus I dilakukan, rata-rata hasil belajar siswa meningkat menjadi 71.66 dengan hasil kumulatif 2150. Peningkatan memang tidak signifikan dikarenakan ada beberapa kekurangan dalam pelaksanaan strategi bermain peran. Namun secara klasikal, rata-rata tersebut sudah melampaui KKM. Setelah kekurangan-kekurangan di siklus I diatasi, pada siklus II nilai kumulatif siswa meningkat pesat menjadi 2770 dengan nilai rata-rata 92.33. Dengan demikian, implementasi strategi bermain peran terbukti mampu meningkatkan hasil belajar siswa kelas 2 MIN 9 Banjar pada materi mengenal pecahan nilai mata uang.

\section{PENUTUP}

Berdasarkan hasil penelitian pada siklus I dan siklus II dapat disimpulkan bahwa strategi bermain peran meningkatkan hasil belajar siswa kelas 2 MIN 9 Banjar pada materi mengenal pecahan nilai mata uang. Sebelum tindakan dilakukan, total kumulatif nilai siswa adalah 2010 dengan rata-rata kelas 67.00. Setelah tindakan siklus I dilakukan, rata-rata hasil belajar siswa meningkat menjadi 71.66 dengan hasil kumulatif 2150. Pada siklus II nilai kumulatif siswa meningkat pesat menjadi 2770 dengan nilai rata-rata 92.33. Setelah siklus II dilakukan, seluruh siswa secara individu mampu mencapai nilai KKM.

\section{DAFTAR PUSTAKA}

Anderson, L., \& Krathwohl, D. A. 2001. Taxonomy for Learning, Teaching and Assessing: A Revision of Bloom's Taxonomy of Educational Objectives

Bandura, Albert. 1977. Social Learning Theory. Prentice-Hall, Inc., New Jersey

Bonwell, C. C., \& Eison, J. A. 1991. Active Learning Creating Excitement in the Classroom. ASHE-ERIC Higher Education Report, Washington DC

Dimyati dan Mudjiono. 2006. Belajar dan Pembelajaran. Jakarta: PT Rineke Cipta.

Driscoll. 2005. Psychology of Learning for Instruction. $3^{\text {rd }}$ Edition. Pearson.

Duch et al., 2001. Duch B.J.,Groh S.E., Allen D.E. (2001). Why problem-based learning? A case study of institutional change in undergraduate education.

Fogarty. 1997. The Mindfull School; How To Integrate The Curricula. Skylight publishing

Hadisubroto. 2000. Model Pembelajaran Terpadu. Jakarta: Gramedia.

Joni, T.R., Pendekatan Cara Belajar Siswa Aktif, Jakarta: Balitbang Depdikbud

Makmun. 1995. Perkembangan Anak. Bandung: Remaja Rosdakarya.

Nana Syaodih Sukmadinata. 2004. Landasan Psikologi Proses Pendidikan. Bandung: PT Remaja Rosdakarya

Slavin, Robert E. 1994. Cooperative Learning. Pearson

Sudjana, Nana. 2009. Penilaian Hasil Proses Belajar Mengajar. Bandung : PT. Remaja Rosdakarya

Sugihartono, dkk. 2007. Psikologi Pendidikan, Yogyakarta : UNY Press.

Supandi. 1992. Strategi Belajar Mengajar Pendidikan Jasmani dan Kesehatan. Jakarta: DEPDIKBUD

Tim Pengembang PDSG. 1997. Pembelajaran Terpadu D-II dan S-II Pendidikan Dasar. Jakarta: Dirjen Dikti, Bagian Proyek Pengembangan Pendidikan Guru Sekolah Dasar.

Trianto. 2007. Model-Model Pembelajaran Inovatif Berorientasi Kontruktivistik. Prestasi Pustaka: Jakarta. 
AL-ADZKA, Jurnal Ilmiah Pendidikan Guru Madrasah Ibtidaiyah Volume VIII, Nomor 02, Hal (125-140)

Desember 2018 